\title{
The Influence and Impact of the Exchange Rate on the Economy
}

\author{
Yuxin Zhao \\ Faculty of Business, University of Nottingham Ningbo, Xi'an, Shannxi, 710068, China
}

\begin{abstract}
This paper analyzes the influence and impact on the exchange rate from several aspects. Firstly, the primary factors influenced by the exchange rate, export, the prices and costs are introduced in this paper. Productivity refers to the increase because the local currency strengthens. Then, it indicates that the exchange rate affects productivity. The last part about influential factors is the effect on the number of tourists. After analyzing the impact of the exchange rate, some suggestions about exchange rate policies are put forward. The exchange rate is an essential element, and it requires to attach importance to both the logical operation and the appropriate use of policy.
\end{abstract}

\section{Introduction}

The exchange rate refers to a currency against another currency in the foreign exchange market. Specifically, it is used to verify the price of one currency expressed by other currencies. Fluctuations of exchange rate have a direct regulating effect on import and export trade between countries. Exchange rate subjects to changes in interest rates, inflation, national politics, and the economy of each country. The foreign exchange market determines the exchange rate. It can be affected by the attitude to market expectations. An excellent market expectation is a prospect of local currency going up. In this case, the local currency will be bought in a large quantity, and the local currency will strengthen. Moreover, macroeconomic policy has a more significant impact on the exchange rate. For example, when a country implements a tight fiscal policy, its currency external exchange rate will strengthen. Apart from these factors impacted on the exchange rate, the exchange rate can give rise to a series of effects on various core elements. The elements such as consumption, export, price, productivity, and the number of foreign tourists will be shown below. Hence, there are different exchange rate policies, floating exchange rate policy, fixed exchange rate policy, as well as pegged exchange rate. This paper will analyze the influence and impact on the exchange rate at first. Then suggestions about how to make proper decisions on the exchange rate policy will be provided with.

\section{The impact of exchange rate on export price}

Export is the most dominant element that will be affected because of the exchange rate. If the local currency per US dollar increases and the local currency depreciates, the amount of export will increase. According to Thorbecke and Kato (2011), some countries import products from Japan and reprocess the product to export again to other countries [6]. As long as the currency of reprocessing country goes up, the amount of export can be restricted. So as for import countries which import from Japan, the appreciation of local currency give rise to a decrease in export. Some argued that this outcome could be different in the export situation in Japan. The unique export product that is used to be reprocessed again and the decrease in reprocessing and export affects the quantity of export in Japan. Thorbecke and Kato (2011) proved that the consumption export would decrease by approximately $30 \%$ on account of the $30 \%$ appreciation of Japanese yen [6]. This data proved that the exchange rate plays an essential role in Japanese export as well. Additionally, the price is commonly regarded as independent variables. However, from the standpoint of the exchange rate, the price could be dependent variables. It is said by Mathias (2015) that the augment of price and difficulty of decisions for vendors, distributors, and sellers are affected by the exchange rate[3]. For instance, the value of dollars was going up, which attributed to an atmosphere of component cost increased, and the market price increased in the eurozone [3]. Besides, in the UK, the phenomenon of steadily increasing costs also appeared. With the increase in cost and component prices, the maintenance and update more and more expensive. In this circumstance, an enormous number of industries would face a harmful effect, and it would be detrimental to the enthusiasm and anticipation of the economy. 


\section{The impact of exchange rate on consumption}

It is suggested that the exchange rate also has some influence on consumption. Although the depreciation of local currency brings less competitivity to a country and expand the export, it has some influence on consumption. The income of workers with high Marginal Propensity to Consumption (MPC) is redistributed to the producer with low MPC on account of inflationary effects of depreciation, which theoretically leads to a decline of consumption [4]. Supposed that a specific local currency appreciates, the ability to purchase foreign commodities strengthen. In this case, foreign commodities became economical to consume and invest, which means that the amount of foreign consumption could increase. As the consumption of foreign goods increases, domestic consumption is likely to decrease. Oskooee, Kutan, and $\mathrm{Xi}$ (2015) used 12 samples to measure the exchange rate in the consumption function[4]. The outcome of the report shows that the exchange rate affected domestic consumption in the nine samples. The cases of Hungary, the Czech Republic, Bolivia, and Malaysia showed that currency depreciation lowers consumption [4]. Therefore, the volatility of the exchange rate affects domestic consumption, and it possibly impacts the development of the economy.

\section{The impact of exchange rate on productivity}

Except for the factors mentioned before, productivity is possibly influenced by the exchange rate. Although productivity and the exchange rate seem to be unrelated, productivity is likely to increase attributes to the appreciation of the local currency. It is precisely be proved by Jeanneney and Hua (2010) that thanks to the appreciation of RMB, the productivity in China increased sharply. A virtuous circle was found in China, the appreciation fostered productivity, and simultaneously the productivity promoted the real exchange rate [2]. Besides, there are differences in economic status between each city in China, and the incremental productivity could assist in reducing the gap. In addition, high productivity plays a role in compensating the loss of international competency.

\section{The impact of exchange rate on the number of foreign tourists}

The volatility of the exchange rate is a crucial issue in the emerging tourism market. As a matter of fact, the incremental exchange rate positively affects the number of foreign tourists and conduces to facilitate the tourism market. Tung (2019) investigated the relationship between the exchange rate and the tourism market from 2006-2018, and figure 1 shows the number of tourists to Vietnam during this period. The data was assembled monthly, and it described that the increase of the exchange rate raised the number of tourists [7]. Research in Vietnam is a useful recommendation for other emerging markets. Tourism markets could empirically respond to the change in exchange rate. Granger tested the causal relationship between the exchange rate and the number of foreign tourists, which concluded a onefold relationship from the exchange rate to the number of tourists [7]. Thus, the exchange rate could be a reference to the tourism market policymakers, and policymakers could efficiently respond to the influence on tourism economy. But it is undeniable that improving the environment of resorts and providing satiation to tourists are also significant.

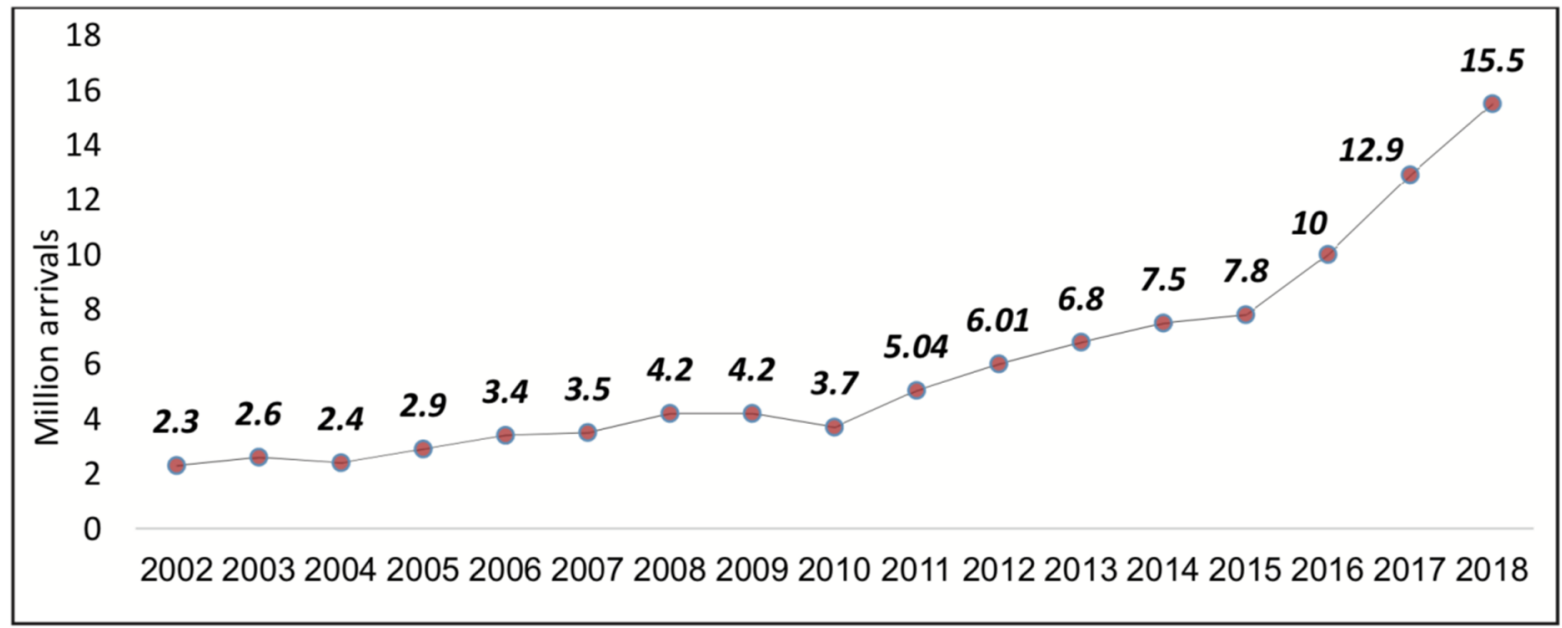

Figure 1. The annual number of tourists to Vietnam[7].

\section{Suggestions}

The exchange rate is an influential element in the economic system that can affect a series of relevant factors shown before. Therefore, each country should operate rationally to reduce the negative influence of the exchange rate and the risky high proportion of damaging the economy. Both reasonable and legal operations between each country are essential to maintenance and improve the economy and relationships among nations. 
Countries are supposed to choose their exchange rate systems and policies that are suitable to ensure the appropriate exchange rate, and conducive to economic development. Fixed exchange rate, floating exchange rate, and the crawling pegged exchange rate are the three major exchange rate systems. The recommendations will be illustrated in the following paragraph.

The floating exchange rate is a policy that permits the foreign exchange market to determine the exchange rate without the intervention of the government. Countries that choose the floating exchange rate policy face a fluctuating exchange rate in the short run. A high proportion of countries in the world choose floating exchange rates such as the United States. The floating exchange rate helps to stem the tide of massive currency speculation because the constant change of the exchange rate makes less allowance to the speculator to benefit. Moreover, the floating exchange rate is beneficial to a country to adjust the balance of payment by depreciating the local currency to prevent the favorable balance of payment from the balance of payment deficit. Sebastian (2007) said that a flexible and changeable exchange rate could reduce the probability of going through a capital flow contraction[5]. The more capital flows, the more beneficial the elastic exchange rate is. However, the floating exchange rate brings more foreign exchange rates to international trade and financial activities. It weakens the monetary discipline under the fixed exchange rate system. It encourages the inflationary tendency of monetary policy so that governments do not have to meet their obligations to maintain fixed exchange rates by suppressing inflation.

The fixed exchange rate is another choice, and the government sets a specific exchange rate. Countries with

import-export oriented economies can benefit from the fixed exchange rate policy, because the stable exchange rate reduces the risk of change. Import and export can contribute to a high ratio of GDP in a country, so the fixed exchange rate provides protection and security for GDP.

Besides, a soft peg is the name of the policy that allows the market to decide the exchange rate, and when the exchange rate is either increasing or decreasing, the central bank will intervene in the market. Another similar policy named hard peg attempts to keep a fixed exchange rate without fluctuations in the short run. The intervention of the central bank is permitted in both the soft peg and hard peg. With the help of government intervention, the economy could be protected from getting into recession that is occurred by the crisis or malignant one side change in the exchange rate. According to Exchange-rate policies (unknown), soft peg policy holds the moderate cost of foreign exchange reserve and adjusts in the long run to reduce the risk of stuck. Nonetheless, if a country pegs the exchange rate, the power of utilizing monetary policy will be given up, and maybe it will cause a higher fluctuation in the foreign exchange market. Furthermore, when a country which pegs the exchange rate faces recession or inflation, and the monetary policy can either be utilized to alter the exchange rate or cope with the inflation and recession[1]. Adopting the expansionary monetary policy and reduce interest rate attributes to a demand reduction and increase of supply. After that, a depreciation of the exchange rate appears and obey the hard peg. In this circumstance, a utilization trade-off between monetary policy and exchange rate needs to consider deliberately. The table 2 trade off the exchange rate policies.

\begin{tabular}{|c|c|c|c|}
\hline Situation & $\begin{array}{l}\text { Floating } \\
\text { Exchange Rates }\end{array}$ & Soft Peg & Hard Peg \\
\hline Large short-run fluctuations in exchange rates? & $\begin{array}{l}\text { Often a lot in the } \\
\text { short term }\end{array}$ & $\begin{array}{l}\text { Maybe less in the short run, but } \\
\text { still large changes over time }\end{array}$ & $\begin{array}{l}\text { None, unless a change in the } \\
\text { fixed rate }\end{array}$ \\
\hline $\begin{array}{l}\text { Large long-term fluctuations in exchange } \\
\text { rates? }\end{array}$ & Can often happen & Can often happen & $\begin{array}{l}\text { Cannot happen unless hard } \\
\text { peg changes, in which case } \\
\text { substantial volatility can occur }\end{array}$ \\
\hline $\begin{array}{l}\text { Power of central bank to conduct } \\
\text { countercyclical monetary policy? }\end{array}$ & $\begin{array}{l}\text { Flexible exchange } \\
\text { rates make } \\
\text { monetary policy } \\
\text { stronger }\end{array}$ & $\begin{array}{l}\text { Some power, although conflicts } \\
\text { may arise between exchange rate } \\
\text { policy and countercyclical policy }\end{array}$ & $\begin{array}{l}\text { Very little; central bank must } \\
\text { keep exchange rate fixed }\end{array}$ \\
\hline Costs of holding foreign exchange reserves? & $\begin{array}{l}\text { Do not need to } \\
\text { hold reserves }\end{array}$ & $\begin{array}{l}\text { Hold moderate reserves that rise } \\
\text { and fall over time }\end{array}$ & Hold large reserves \\
\hline $\begin{array}{l}\text { Risk of being stuck with an exchange rate that } \\
\text { causes a large trade imbalance and very high } \\
\text { inflows or outflows of financial capital? }\end{array}$ & Adjusts often & $\begin{array}{l}\text { Adjusts over the medium term, if } \\
\text { not the short term }\end{array}$ & $\begin{array}{l}\text { May become stuck over time } \\
\text { either far above or below the } \\
\text { market level }\end{array}$ \\
\hline
\end{tabular}

Figure 2.

Table of exchange rate policies[1].

There is no specific regulation to choose exchange rate policies to reduce the negative influence of the exchange rate. It is suggested by Exchange-rate policies (unknown) that countries accomplish the four economic targets, a steady increase of economy, low inflation, low unemployment, and sustainable trade of balance, which can get more and more prosperous in arbitrary exchange rate policy[1]. An exchange rate policy is not a medical 
cure to rescue the countries without the four economic targets. Formulating a precious and comprehensive exchange rate policy is essential. Moreover, a correct understanding of countries' operation system and capability is also significant for deciding a rational and appropriate exchange rate policy. There is not a verified best exchange rate policy, but the best policy is the most suitable one for the local economic climate.

\section{Conclusion}

The influence and impact of the exchange rate are extensive, and the analysis should be comprehensive. This essay firstly analyzes the core factors that influenced by the exchange rate, and it finds that the impact on export is the most direct and remarkable. With the change in the exchange rate, the price and cost are affected in the foreign exchange market, and the productivity is influenced, respectively. The last factor mentioned in the essay is the number of foreign tourists, which shows that the increase in the exchange rate raises the number of tourists. After that, this essay offers four core exchange rate policies with pros and cons to choosing in diverse situations. The floating exchange rate is the most widely used choice in the world. Moreover, the central bank has the responsibility to intervene to manipulate both the soft peg and hard peg. It is illustrated that there is no definitely the best policy to choose from. The best outcome of utilizing exchange rate policy is the most appropriate policy for a high qualified implemented country. To sum up, the foreign exchange market is tightly related to the exchange rate, so the logical operation of each country and well-used policy could give rise to a prosperous market atmosphere.

\section{Acknowledgment}

First and foremost, I would like to show my deepest gratitude to my teachers and professors in my university, who have provided me with valuable guidance in every stage of the writing of this thesis. Further, I would like to thank all my friends and roommates for their encouragement and support. Without all their enlightening instruction and impressive kindness, I could not have completed my thesis.

\section{References}

1. Exchange-rate policies (unknown) Available at: https://courses.lumenlearning.com/wmmacroeconomics/chapter/exchange-rate-policies/ (Accessed at: 23 February 2019)

2. Jeanneney S. G. and Hua P. (2010) 'How does real exchange rate influence labour productivity in China?', Science Direct 22(4), pp. 628-645.

3. Mathias K. (2015) 'The exchange rate effect.', ProQuest, Available at: https://search-proquestcom.ezproxy.nottingham.edu.cn/docview/16842990 59/fulltextPDF/30A6BD600C6446BPQ/1?accountid $=16676$ (Accessed at: 27 February 2019)
4. Oskooee M. B., Kutan A. M. and Xi D. (2015) 'Does exchange rate volatility hurt domestic consumption? Evidence from emerging economics.', Science Direct 144, pp. 53-65.

5. Sebastian E. (2007) 'Capital Controls, Capital Flow Contractions and Macroeconomics Vulnerability.', ProQuest, Available at: https://search-proquestcom.ezproxy.nottingham.edu.cn/docview/16886693 59?rfr_id=info\%3Axri\%2Fsid\%3Aprimo (Accessed at: $27 \overline{\text { February } 2019)}$

6. Thorbecke W. and Kato A. (2011) 'The effect of exchange rate changes on Japanese consumption export.', Science Direct 24(1), pp. 64-71.

7. Tung L. T. (2019) 'Does exchange rate affect foreign tourist arrivals? Evidence in an emerging tourist market.', Management Science Letters 9(8), pp. 1141-1152, doi: 10.5267/j.msl.2019.5.001 